\title{
Heritage Treasures And Gifts: Improving Controls And Systems In A Not For Profit Environment
}

Robert C. Zelin II, (Email: Robert.zelin@mnsu.edu), Minnesota State University, Mankato Jane E. Baird, (Email: Jane.baird@mnsu.edu), Minnesota State University, Mankato

\section{INTRODUCTION}

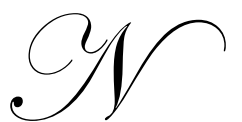

ot-for-profit organizations often rely heavily on volunteers to help them achieve their goals on very limited budgets. Often, these organizations are especially in need of volunteers with specific skills not possessed by the average volunteer. Such is the case with the County Historical Society (The Society), which is in need of help with certain aspects of its museum gift shop operations. Most of the volunteers and staff of the organization are avid history buffs, but know little about running a business and even less about accounting and systems related processes. Therefore, the organization has approached your professor to ask for your assistance. The Society would like to seek the benefit of your knowledge of accounting systems and internal controls to help it improve operations and financial reporting for the gift shop. A previous group of students has documented the operations in narrative form as part of a class project. The Society would now like specific recommendations for ways to improve internal controls. It would also like to begin to upgrade its systems for inventory tracking, starting with its records for consignment inventory.

\section{HERITAGE TREASURES AND GIFTS}

Heritage Treasures and Gifts (HTG) is a small shop operating for the benefit of The Society, a non-profit organization with the mission of preserving the county's history and educating the public about that history. The HTG shop contains items for sale that are consistent with The Society's mission, such as books that provide information about the history of the county, reproductions of historical pictures, postcards, and local maps. Other small items are also available in the gift shop, including reproduction old-time toys and dolls, old fashioned Christmas ornaments, souvenir t-shirts and coffee mugs, and a variety of items brought in on consignment. Consignment items consist mainly of hand-crafted products from local artisans and souvenirs from the BT Society, a group which celebrates the accomplishments and writings of a famous author of children's books depicting the local area in the early 1900s.

\section{THE SOCIETY}

The Society's operation includes an historical artifact museum display (approximately 5000 square feet), the HTG shop, and an archival library. The library houses numerous documents and photographs documenting the history of the county and its inhabitants, while the museum displays other historical items of general interest to the public. All of the Museum's facilities are located in a building rented from the city government. Patrons enter into a central hallway, with the entrance to the Society's offices and meeting rooms on the right, the museum entrance door to the left and the archival library at the end of the hall. The building has a sophisticated burglar alarm and fire alarm system that was installed by the Society. The Museum has three employees: Kathy Taylor, the full-time Executive Director, Sally Wilson, a full-time Museum Assistant, and an Archive Librarian, Mike Nelson. The Society runs on a "shoe-string" budget which does not afford it the opportunity to hire any additional staff, even on a part-time basis. Therefore, a heavy reliance is placed on volunteers. The Museum is directed by a volunteer Board of Trustees, consisting of twelve members from the community. The officers of the Board of Trustees include a president, a vice president, a secretary, and a treasurer. Board members are expected to contribute volunteer hours to the Society in addition to attending and participating in monthly Board meetings, so many Board members belong to Society committees and/or participate in fund raising and other events. 


\section{THE HTG SHOP OPERATIONS}

The HTG shop is located inside the museum, with no separate outside entrance. Therefore, it is open whenever the museum is open. The museum and HTG hours are from 10:00 am to 12:00 pm and 1:00 pm to 4:00 pm Tuesday through Saturday. Because of the Society's limited staffing, it closes the facility during the noon hour while the employees are at lunch. Even during operating hours, the door to the museum is usually kept locked unless somebody is in there. There is a sign on the door indicating that visitors should come to the main office if they want to tour the museum. A Society employee (usually the Museum Assistant) will then open the museum for the patron and open the HTG shop as well. On an average day, the Society would have no more than 10 to 20 visitors to the museum and HTG shop. However, there are times throughout the year when large tour groups visit the museum, particularly during the summer months. These tours can be particularly lucrative for the HTG shop. During the school year the museum is often a part of school field trips, and some sales of small items are made in the shop, but the children are not significant purchasers of products. The Christmas season is also a busy time for the shop, with customers looking for unusual gifts for friends and relatives.

\section{Inventory Purchases}

Inventory for the gift shop is ordered by the Museum Assistant every three to four months. A volunteer Gift Shop Committee decides what is to be ordered for the HTG shop and when it is necessary to order more items. Because it is comprised solely of volunteers, the committee does not always meet on a regular basis to review the store's inventory status. The purchasing decision is made without any formal criteria, but the committee does ask for suggestions from the Society's director, board members, and volunteers regarding what types of items they would like to see in the shop. When a decision is made by the committee that products need to be ordered, the committee chairperson gives the list of items and quantities desired to the Museum Assistant, who then sends in the order by mail.

When the inventory arrives, the inventory is counted and checked against the order by either the Museum Assistant or the Director to ensure that everything has been received. The Museum Assistant then enters the inventory into an Excel spreadsheet. The attached bill is given to the Director to be paid. The Director writes out the checks for inventory purchases, using the North Bank checking account, at the same time he pays the Society's other bills. On average, this is done twice per month. The checks are then given to the treasurer or the president of the Board of Trustees for signature, the only two authorized check signers for The Society. The Society's policies are that each check requires only one signature, but significant non-routine transactions must have prior board approval. The Director records the transactions into the Society's accounting records using QuickBooks. The checkbook consists of a hand written business style check, with a stub left in the book for recording information about the check. The Society does not use QuickBooks for generating checks. The checking account is reconciled at each statement date by the treasurer.

The inventory records are primarily kept throughout the year on the Museum Assistant's Excel spreadsheet. At the end of the year, prior to the Society's required annual financial statement audit, the inventory data from the spreadsheet and a physical count of the inventory are used to update the inventory account in QuickBooks. Inventory for the shop is counted once each year, at year-end, by the Museum Assistant, the Director, or volunteers. There are usually at least two people conducting the inventory account each year. The treasurer assists with the updating of QuickBooks at year end in preparation for the audit. The Society reports its HTG shop inventory on the First-In, First-Out (FIFO) method. The inventory account has not been material to the Society's financial statements and, therefore, is not closely looked at by the Society's auditors.

\section{Consignment Goods}

The HTG shop has four regular consignors, with others that sometimes consign goods on an irregular basis. During the Christmas holiday season, approximately 10 to 12 consignors usually sell products through the HTG shop. The Society does not charge a fee to consignors for selling things out of the HTG shop. Instead, it retains a commission that is based on a percentage of the sales price on all of the consignment items that are sold. The 
commission percentage varies among consignors. This is negotiated by the Museum Assistant when the goods are brought in. The sales price for each item is set by the consignor. Approximately every two months, the Museum Assistant counts the consignment inventory for each consignor and compares the quantity counted with the quantity brought in to determine how much must have been sold. The commission amount is then calculated based on the amount determined to have been sold. The net due to the consignor is then calculated as the sales price for all goods sold, less the commission. A report is then given to the Director, who writes checks to the consignors and then enters the transaction into QuickBooks. The consignment goods are also counted at the end of the year, but are not recorded on the Society's balance sheet since they are not owned by the Society.

\section{Sales And Cash Receipts}

Sales in the HTG shop are usually made by the Museum Assistant, although the shop is sometimes operated by the Director or by volunteers. The Society accepts cash and checks, but does not accept credit cards because of the large transaction fees it would be charged. Two forms of identification are required for patrons writing checks. There is a small, very simple cash register in the HTG shop, but it does not have a built-in receipt tape. Therefore, while all sales are run through the cash register, the customers are given hand-written receipts. The sales price for each item is entered into the cash register, then a subtotal is calculated by pressing one button, and tax is added on by pressing another button. Whoever is running the cash register then writes down on the customer's receipt what items were purchased and the total price. The prenumbered receipts are in duplicates, so one copy is given to the customer and one copy is maintained in the shop in a file under the counter (filed numerically). Cash and checks are placed directly in the register for each sale. The Director would like to have a better cash register, but space is extremely limited in the shop and funds are even more limited, so purchase of a better, larger register is not feasible at this time.

The Society's policy is to maintain a minimum balance of $\$ 80$ in the cash register. The Director reconciles the cash and checks from the register to the sales receipts every time the money is counted down, which is approximately twice each month, depending on the level of activity in the museum. He then uses the totaled sales receipts figures to record the sales amount and the cash receipts into the accounting records. The sales receipts are then filed numerically in the main office. He prepares a deposit slip for the bank, together with cash and checks from other sources (unrestricted donations, membership fees, and library research fees) and takes the cash to the bank for deposit into the general checking account. When the director prepares the deposit slip, he also endorses each check by stamping "for deposit only in account (the Society's account number)" on the back of each check.

\section{Offsite Sales}

Merchandise from the store is also sold at special events at offsite locations. For example, the Society operates a booth at the county fair. It also operates fundraising program events at local historical houses and other locations. The day of the event, the Museum Assistant boxes up a selection of inventory from the HTG shop to be offered for sale at the event. If the Museum Assistant will be staffing the event, she takes the inventory with her. Otherwise, a volunteer picks up the inventory before the event.

Usually, the cash register is taken to the event, but sometimes a cash box is used. Sales at these offsite locations tend to be more hectic than in the shop, so a minimum of two people staff the sales table. Depending on the time and day, both people might be volunteers, while at other times the Museum Assistant is assisted by one volunteer. One of the individuals typically operates the cash register while the other completes the receipt. After the event, the two individuals working the sales table total up the cash in the register or cash box, and write the total down on a sheet of paper. The register or cash box, with the cash inside, is then returned to the museum along with the unsold inventory, and placed in the HTG shop. If the cash box is used, the cash, checks, and receipts are transferred to the cash register in the shop when the cash and inventory are dropped off. The inventory is unpacked from the boxes and arranged in the shop the next working day by the Museum Assistant.

The Director and Museum Assistant are finding that as the sales activity in the Museum continues to grow, efficiency over the sales function and the record keeping is becoming a concern. In addition, they would like to 
have more timely information about what products are selling well and need to be reordered and what products should perhaps be discontinued. There is limited space in the gift shop, so the Society cannot stockpile a lot of inventory. Also, the pool of volunteers for the Society has been diminishing over the past several years, so relying solely on a volunteer Gift Shop Committee for purchasing decisions might not be a viable option in the long term. The Director would like you to document the sales and cash receipts functions in a flowchart to facilitate review of the procedures. He would also like to hear any recommendations you have for improving procedures in the gift shop. He would like to begin to better automate the shop's inventory records. The Society currently has QuickBooks and Microsoft Office products on its computers. To start, the Director would like you to design a system to handle the consignment inventory records using Microsoft Access.

\section{Required:}

1. Use the systems flowchart method to document the HTG shop's procedures over sales and cash receipts (from sale to deposit of cash in bank and recording of transactions).

2. Identify any internal control weaknesses apparent in HTG's procedures over sales, cash receipts, inventory purchases and inventory recording, including consignment sales and offsite sales. Discuss why these deficiencies could be problems to the organization and ways that the organization might reduce or correct the deficiencies, keeping in mind the limited resources available.

3. Using Access and Tables One, Two, and Three, create a database with the following elements:

A data entry form for consignor data

A data entry form for consigned inventory items

A data entry form for consignment inventory transactions

A detailed sales report that is grouped by consignor with totals and percentage calculations for each group (use the one month of data provided)

An ending consignment inventory report

A consignor payment report (total sales for each consignor less the applicable commission)

A price label for consigned items (including item number, item description and price)

An opening switchboard that aids in navigation of various forms and reports and opens when the database is opened

\begin{tabular}{|c|c|c|c|c|c|c|c|c|}
\hline \multicolumn{1}{|c|}{ Cable One } \\
Consignor Data \\
\hline $\begin{array}{c}\text { Consignor } \\
\text { Number }\end{array}$ & Company Name & Company Address & City & State & $\begin{array}{c}\text { Zip } \\
\text { code }\end{array}$ & Phone & $\begin{array}{c}\text { Contact } \\
\text { Name }\end{array}$ & $\begin{array}{c}\text { Comm. } \\
\text { Rate }\end{array}$ \\
\hline $\mathbf{1}$ & BT Society & $\begin{array}{c}116 \text { Mockingbird } \\
\text { Lane }\end{array}$ & $\begin{array}{c}\text { Valley } \\
\text { View }\end{array}$ & MN & 56003 & $507999-2121$ & $\begin{array}{c}\text { Betty } \\
\text { Books }\end{array}$ & 0.05 \\
\hline $\mathbf{2}$ & $\begin{array}{c}\text { Uncle Ben's Hand } \\
\text { Made Wooden Toys }\end{array}$ & 210 Watoga Street & $\begin{array}{c}\text { Valley } \\
\text { View }\end{array}$ & MN & 56003 & $507999-3241$ & $\begin{array}{c}\text { Ben } \\
\text { Spencer }\end{array}$ & 0.15 \\
\hline $\mathbf{3}$ & Valley Pottery & 815 Clay Road & $\begin{array}{c}\text { Valley } \\
\text { View }\end{array}$ & MN & 56003 & $507999-8499$ & $\begin{array}{c}\text { Marge } \\
\text { Madson }\end{array}$ & 0.10 \\
\hline $\mathbf{4}$ & Jackie's Jewels & $\begin{array}{c}1000 \text { Silver Maple } \\
\text { Road }\end{array}$ & $\begin{array}{c}\text { Valley } \\
\text { View }\end{array}$ & MN & 56003 & $507999-4000$ & $\begin{array}{c}\text { Jackie } \\
\text { Jones }\end{array}$ & 0.15 \\
\hline
\end{tabular}




\begin{tabular}{|c|c|c|c|c|}
\hline \multicolumn{2}{|c|}{ Consigned Inventory Items } \\
\hline Item Number & Item Name & Unit Sales Price & $\begin{array}{c}\text { Quantity on } \\
\text { Hand 6/30/07 }\end{array}$ & $\begin{array}{c}\text { Consignor } \\
\text { Number }\end{array}$ \\
\hline 1 & BT Society Mug & $\$ 5.50$ & 5 & 1 \\
\hline 2 & BT Society T Shirt & $\$ 10.50$ & 7 & 1 \\
\hline 3 & BT Doll House & $\$ 35.00$ & 1 & 1 \\
\hline 4 & BT Book One & $\$ 12.50$ & 4 & 1 \\
\hline 5 & BT Book Two & $\$ 12.50$ & 3 & 1 \\
\hline 6 & BT Book Three & $\$ 12.50$ & 3 & 1 \\
\hline 7 & BT Book Four & $\$ 12.50$ & 5 & 1 \\
\hline 8 & Fire Engine & $\$ 10.00$ & 2 & 2 \\
\hline 10 & Boat & $\$ 10.00$ & 2 & 2 \\
\hline 11 & Truck & $\$ 7.00$ & 2 & 2 \\
\hline 12 & Train Set & $\$ 125.00$ & & 2 \\
\hline 13 & Vase & $\$ 62.00$ & & 3 \\
\hline 14 & Large Bowl & $\$ 28.00$ & & \\
\hline 15 & Medium Bowl & $\$ 20.00$ & & 2 \\
\hline 16 & Silver earrings & $\$ 12.00$ & 5 & 3 \\
\hline 17 & Blue bead necklace & $\$ 12.00$ & 4 & 4 \\
\hline 18 & Red bead necklace & $\$ 10.00$ & & 4 \\
\hline 19 & Silver ring & $\$ 120.00$ & 5 & 4 \\
\hline 20 & Onyx earring necklace set & & 3 \\
\hline
\end{tabular}

\section{TEACHING NOTES}

This case is designed for use in an Accounting Information Systems course, an Auditing course, or a capstone accounting course. The case requires students to critically evaluate the operations of a not-for-profit organization's gift shop, identifying internal control weaknesses present and proposing improvements. Students obtain practice in flowcharting by documenting the organization's cash receipts and revenue functions. They also demonstrate their technology skills by using Microsoft Access to design a system for tracking and reporting on the organization's consignment sales and consignment inventory. Students get exposed to the needs of nonprofit organizations and the challenge of establishing internal controls within the constraints of extremely limited resources.

The case can be used as an individual assignment or as a team assignment. Students can present their results orally if the instructor wishes to assess presentation skills, or, alternatively, the students can turn in their answers in writing. One option is to have the students turn in a written report with their flowcharts and Access documentation and then orally present their suggestions for improving the entity's internal controls. The flowcharting portion of the assignment should take approximately two to four hours to complete. The access portion should take an average of six hours for a moderately skilled student, while the internal control report could take two to six hours. The parts are not interdependent, so each could be a stand alone assignment.

This case is based on an actual gift shop operated by a county historical society. However, some facts have been altered slightly and details have been added to meet the educational objectives of the case and disguise the identity of the organization.

Student solutions will vary significantly due to the subjective nature of the assignment. Sample solutions can be obtained from the authors by instructors via email requests. 


\begin{tabular}{|c|c|c|c|c|}
\hline \multicolumn{5}{|c|}{$\begin{array}{c}\text { Table } 3 \\
\text { Consignment Inventory Transactions }\end{array}$} \\
\hline Transaction Number & Date & Item Number & Quantity In & Quantity Out \\
\hline 1 & $7 / 1 / 2007$ & 1 & 10 & 0 \\
\hline 2 & $7 / 1 / 2007$ & 2 & 10 & 0 \\
\hline 3 & $7 / 1 / 2007$ & 3 & 2 & 0 \\
\hline 4 & $7 / 1 / 2007$ & 4 & 5 & 0 \\
\hline 5 & $7 / 1 / 2007$ & 5 & 5 & 0 \\
\hline 6 & $7 / 1 / 2007$ & 6 & 5 & 0 \\
\hline 7 & $7 / 1 / 2007$ & 7 & 5 & 0 \\
\hline 8 & $7 / 4 / 2007$ & 4 & 0 & 1 \\
\hline 9 & $7 / 4 / 2007$ & 1 & 0 & 2 \\
\hline 10 & $7 / 6 / 2007$ & 12 & 0 & 1 \\
\hline 11 & $7 / 6 / 2007$ & 13 & 0 & 1 \\
\hline 12 & $7 / 6 / 2007$ & 8 & 0 & 1 \\
\hline 13 & $7 / 6 / 2007$ & 9 & 0 & 1 \\
\hline 14 & $7 / 10 / 2007$ & 8 & 10 & 0 \\
\hline 15 & $7 / 10 / 2007$ & 9 & 10 & 0 \\
\hline 16 & $7 / 10 / 2007$ & 10 & 10 & 0 \\
\hline 17 & $7 / 10 / 2007$ & 11 & 1 & 0 \\
\hline 18 & $7 / 10 / 2007$ & 1 & 0 & 1 \\
\hline 19 & $7 / 10 / 2007$ & 4 & 0 & 1 \\
\hline 20 & $7 / 14 / 2007$ & 17 & 0 & 2 \\
\hline 21 & $7 / 14 / 2007$ & 19 & 0 & 1 \\
\hline 22 & $7 / 14 / 2007$ & 12 & 1 & 0 \\
\hline 23 & $7 / 14 / 2007$ & 13 & 3 & 0 \\
\hline 24 & $7 / 14 / 2007$ & 14 & 3 & 0 \\
\hline 25 & $7 / 20 / 2007$ & 2 & 0 & 3 \\
\hline 26 & $7 / 20 / 2007$ & 3 & 0 & 1 \\
\hline 27 & $7 / 20 / 2007$ & 11 & 0 & 1 \\
\hline 28 & $7 / 21 / 2007$ & 10 & 0 & 2 \\
\hline 29 & $7 / 25 / 2007$ & 15 & 0 & 1 \\
\hline 30 & $7 / 30 / 2007$ & 1 & 0 & 1 \\
\hline 31 & $7 / 30 / 2007$ & 16 & 0 & 1 \\
\hline 32 & $7 / 30 / 2007$ & 20 & 0 & 1 \\
\hline
\end{tabular}

